\title{
Area Studies and the Development of Global Labor History
}

\author{
Andreas Eckert
}

During the 1980 s and 1990s, area studies and labor history both experienced a period of "baisse" and were given numerous obituaries. Harry Harootunian, a historian of Japan, labeled area studies a "dinosaur" and regarded, for instance, Asian studies as an illusion because, as he argued, there is no such thing as "Asia."1 David Ludden, a specialist of South Asia, lamented that "there is no theory of area studies or of area-specific knowledge, only a set of institutional, personal, and fragmented disciplinary, market and professional interests that converge chaotically in questions of funding."2 Mahmood Mamdani, a political scientist from Uganda teaching in New York, stated that the area studies enterprise is underpinned by two problematic core methodological claims. "The first sees state boundaries as boundaries of knowledge, thereby turning political into epistemological boundaries." This led to the rule that every area studies specialist "must cultivate his or her own 'local' patch." The second methodological claim he criticized is "that knowledge is about the production of facts. This view translates into a stubborn resistance to theory in the name of valorizing the fact." However, "the single most important failing of area studies is that it has failed to frame the study of the 'third world' in broad intellectual terms."3 After 9/11, Middle Eastern Studies in particular were suspected of cooperating

1 See Harry Harootunian, History's Disquiet: Modernity, Cultural Practice, and the Question of Everyday Life (New York, 200o), 41ff. See also Miyoshi Masao and Harry Harootunian, eds., Learning Places: The Afterlives of Area Studies (Durham, NC, 2002). For a more ambivalent view of the example of Africa, see Paul Tiyambe Zeleza, ed., The Study of Africa, Vol. I: Disciplinary and Interdisciplinary Encounters (Dakar/Oxford, 2006); Vol. II: Global and Transnational Encounters (Dakar/Oxford, 2007).

2 David Ludden, Area Studies in the Age of Globalization (January 1998), http://www.sas.upenn .edu/ dludden/GlobalizationAndAreaStudies.htm.

3 Mahmood Mamdani, When Victims Become Killers. Colonialism, Nativism, and the Genocide in Rwanda (Oxford, 2001), XXII-XIV. This type of critique follows the path set by Edward Said's Orientalism (New York, 1978). A good introduction to the effects of Said's study is provided by Ulrike Freitag, "The Critique of Orientalism," in Companion to Historiography, ed. Michael

(C) ANDREAS ECKERT, 2018 | DOI:10.1163/9789004386617_009

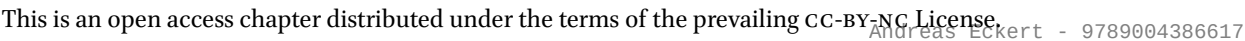


with "the enemy"4 The "crisis" of labor history began somewhat earlier. One could even say that rarely has a sub-discipline been buried so often and with such vigor as has labor history. ${ }^{5} \mathrm{~A}$ widespread disillusionment about the possibilities of labor history has emerged since the 1980s. As Marcel van der Linden argues:

Many labour historians have viewed the state of their discipline as a protracted crisis. First, the emerging paradigms of women's and ethnic history showed that there had been giant blank spots on labour history's maps, and that filling in these blanks would necessitate a complete rewriting of the old narratives. Second, the unilinear conception of class consciousness that had long been dominant came into question. ${ }^{6}$

Due to growing uncertainty about its organizing categories, labor history began to lose its character as a discipline. The distinction between labor history and historiographical branches, such as women's history, ethnic studies, anthropology, and sociology, began to dissolve. Conceptual difficulties and political disappointments further fueled the impression of a state of crisis. According to William Sewell Jr., this "crisis" was due to the fact that labor history was too embedded in the metanarrative of proletarianization. The thesis of proletarianization brings together, as Sewell points out, a number of processes, and while acknowledging variation, treats the overall trend as universal: Cultivators and artisans are deprived of access to means of production, they move to cities or are forced into insecure wage labor jobs on farms, their skills are devalued, and even tighter forms of managerial control are devised. Meanwhile, workers acquire a sense of their collective identity as the sellers of labor power, and their traditions of artisanal autonomy or republican assertiveness are rechanneled into class identity; they build organizations, go on strike, and collectively challenge capital. According to Sewell, this proletarianization thesis pays "insufficient attention to the profoundly uneven and contradictory

Bentley (London/New York, 1997), 620-638; as a short introduction, Conor McCarthy, The Cambridge Introduction to Edward Said (Cambridge, 2010).

4 This was especially true in the United States. See Joel Beinien, "The New McCarthyism: Policing Thought about the Middle East," in Academic Freedom after September n, ed. Beshara Doumani (New York, 2006), 237-266. For the long term effects of 9/11 on Middle Eastern Studies, see Seteney Shami and Cynthias Miller-Idriss, eds., Middle East Studies for the new Millennium. Infrastructures of Knowledge (New York, 2016).

5 Kim Christian Priemel, "Heaps of Work. The ways of labour history," in H-Soz-Kult, 23 January 2014, http://www.hsozkult.de/literaturereview/id/forschungsberichte-1223.

6 Marcel van der Linden, Transnational Labour History. Explorations (Aldershot, 2003), 2. 
character of changes in productive relations, not to mention the role of discourse and politics in labor history."

More recently, there has been a recurrent interest in area studies as well as in themes related to labor and work. This trend is closely linked with the rise of global history. ${ }^{8}$ For a while, conceptual debates very much dominated this field. The discussions about various approaches oscillated between two kinds of ideal types: Relatively rigorous distinctions between world history, global history, and transnational history contrasted with more fluid conceptualizations of the field. ${ }^{9}$ Jürgen Osterhammel represents the former approach by insisting on a clear distinction between transnational, world-historical, and global approaches. Transnational history, he suggests, is primarily concerned with inter-European relationships and their transatlantic connections. Moreover, transnational histories generally examine shorter time periods and are less concerned with universal patterns of connectivity. Notwithstanding its careful attention to historical multiplicity, by contrast, world history aims specifically to explain such general tendencies. Hence, as Osterhammel argues, it examines developments over the longue durée and across much larger regions, as it privileges transcultural relations. He conceived global history in much narrower terms: As an approach that historicizes global entanglements. Thus it examines developments that originated in the middle of the nineteenth century, and that still characterize the interconnectedness of the word today. Osterhammel carefully distinguishes global history, then, from the history of globalization. While the former in his view explores the contacts and

7 See William Sewell, Jr., "Toward a Post-materialist Rhetoric for Labor History," in Rethinking Labor History: Essays in Discourse and Class Analysis, ed. Lenard A. Berlanstein (Urbana, 1993), 15-38 (quote: 18). On the "crisis" of labor history see also, among many others, David Brody, "Labor History, Industrial Relations, and the Crisis of American Labor," ILR Review 43, no. 1 (1989): 7-18; Marcel van der Linden, ed., The End of Labour History? (Cambridge, 1994).

8 The literature on global history is vast by now. Among many others, see Sebastian Conrad, What is Global History? (Princeton, 2016); Dominic Sachsenmeier, Global Perspectives on Global History. Theories and Approaches in a Connected World (Cambridge, 2010), 112; James Belich et al., eds., The Prospect of Global History, (Oxford, 2016); Maxine Berg, ed., Writing the History of the Global. Challenges for the 21st Century (Oxford, 2013); Sven Beckert and Dominic Sachsenmaier, eds., Global History Globally (London/New York, 2018).

9 See Katja Naumann, "(Re)Writing World History in Europe," in A Companion to World History, ed. Douglas Northrup (Oxford, 2012), 478-496, here: 483 f. In addition, one finds numerous debates and suggestions for neologisms. One was coined by area studies researches at the Center for Modern Oriental Studies in Berlin: “Translocal history' expresses the desire to treat neither 'cultures' nor 'regions' nor 'nations' as fixed entities, but to view all definitions of locality as constructs and —at least partly—as the results of global entanglements." See Ulrike Freitag and Achim von Oppen, eds., Translocality. The Study of Globalizing Processes from a Southern Perspective (Leiden, 2010); Sachsenmaier, Global Perspectives, 159. 
interactions between various global networks, the history of globalization suggests a master narrative chronicling the continuous intensification of exchange and interdependencies. ${ }^{10}$

Other authors have opted for a more integrative approach, stressing the common elements between world, global, and transnational histories. They argue that all these approaches share some perspectives: Whether they are inspired by world-system theory, analyze different civilizations, insist on multiple modernities, write the history of globalization, or build on postcolonial studies, they all reject modernization theory and seek to reconstruct "modernity" as a fully relational category. Moreover, these authors insist that world and global history no longer postulate a universal past, no longer mean a teleological view of historical development, and no longer attempt to represent the world in its spatial and temporal reality. ${ }^{11}$ Building on these thoughts, Sebastian Conrad later defined the core concerns of this field:

... with mobility and exchange, with processes that transcend borders and boundaries. It takes the interconnected world as its point of departure, and the circulation and exchange of things, people, ideas, and institutions are among its key subjects. A preliminary and rather broad definition of global history might describe it as a form of historical analysis in which phenomena, events, and processes are placed in global contexts. ${ }^{12}$

Dominic Sachsenmaier even refers to the "necessary impossibility of defining global history" and argues that despite the growing prominence of global history during the past two decades, the various field designations have not crystallized into a set of rivalling schools but, on the contrary, have become increasingly enmeshed with each other. Therefore, he continues, it is not possible to categorically distinguish global history from fields such as transnational history or world history. "Rather, global history—like many other terms—can

$10 \quad$ Jürgen Osterhammel, Geschichtswissenschaft jenseits des Nationalstaates. Studien zur Beziehungsgeschichte und Zivilisationsvergleich (Göttingen, 2001); Jürgen Osterhammel, "Weltgeschichte. Ein Propädeutikum," Geschichte in Wissenschaft und Unterricht ${ }_{5} 6$ (2005): 452-479; Jürgen Osterhammel, "World History," in The Oxford History of Historical Writing, Vol.5, eds. Axel Schneider and Daniel Woolf (Oxford, 2011), 93-112. See also Margarete Grandner et al., eds., Globalisierung und Globalgeschichte (Vienna, 2005).

11 Sebastian Conrad and Andreas Eckert, "Globalgeschichte, Globalisierung, multiple Modernen: Zur Geschichtsschreibung der modernen Welt," in Globalgeschichte. Theorien, Ansätze, Themen, eds. Sebastian Conrad, Andreas Eckert, and Ulrike Freitag (Frankfurt, 2007), 7-49. 
be taken as shorthand for a larger academic trend which we may also choose to call the 'global trend' in historiography."13

This chapter argues that both area studies and labor history profited from the emergence of global history, while at the same time these two fields fueled and shaped global approaches in historiography. The chapter will first analyze more broadly the entanglements between area studies and global history before looking more closely at the crucial role of area based history writing for global labor history. A set of questions structure this essay: Did labor history employ a particular sensitivity to the knowledge and insights of area studies and thus avoid some of the pitfalls of the global turn? And which complications did the combination of global perspectives and the incorporation of area based knowledge create in the field of labor history? What are the effects of the huge differences between world regions in the availability of relevant data and source material on the writing of global labor history? Did the global turn only include working on areas beyond the North Atlantic realm, or also working with scholars from these areas?

\section{Scenes from a Marriage: Area Studies and Global History}

Area Studies have been an important factor in the rise of global history in many parts of the world. It is even safe to say that a crucial impulse behind the (re-)emergence of global history in the European academy was a reaction against Eurocentrism of agency (the assumption that it has been mostly Europeans, or at least Westerners, who have changed the world) and Eurocentrism of concept (the dominance in history and social sciences of models derived from the analysis of European/Western experience, even when the object of investigation is experience elsewhere). ${ }^{14}$ While the former exaggerates European exceptionalism, the latter entails the opposite: The long-standing tendency to "naturalize" European history by treating it as the norm, and the histories of other world regions as exceptions that need explanation. Hence the arguably most fundamental intellectual requirement for the development of global history as a field or as an approach was the massive growth of historical research on the non-Western world that has occurred since 1945, and especially since

\footnotetext{
13 Sachsenmaier, Global Perspectives, 70, 78.

14 As Eric Vanhaute puts it: "Much of the drive for a 'new' global history started with the aim to surpass or delegitimize the 'old' Eurocentric stories of the rise of a unified world." Eric Vanhaute, "Who is afraid of global history? Ambitions, pitfalls and limits of learning global history," Österreichische Zeitschrift für Geschichtswissenschaft 20, no. 2 (2009): 22-39, here: 22.
} 
1960. In the UK, for example, specialists on parts of Asia and Africa such as Christopher Bayly, William Gervase Clarence-Smith, and Gareth Austin became early protagonists in the writing and institutionalizing of global history. ${ }^{15}$

According to David L. Szanton, the task of area studies is to know, analyze, and interpret another culture, a multidisciplinary effort in translating and "to make the assumptions, meanings, structures, and dynamics of another society and culture comprehensible to an outsider."16 Conventional wisdom has it that area studies were "invented" in post-World War II North America, but this field has earlier roots, not only in the United States, but also in Europe. ${ }^{17}$ Nevertheless, the U.S. was crucial as a pacemaker for developing institutional frameworks for area studies. ${ }^{18}$ Cold War concerns, and the conviction of North American elites that the country would need to play a considerably larger international role after World War II than it had done before, provided the major impetus in founding and funding area studies in the U.S. However, many scholars involved in this field soon criticized the link between their research and teaching and the "national interest" of the United States. The different views most dramatically clashed during the Vietnam War, but were also apparent, for instance, in the context of Latin America. ${ }^{19}$

The events of $9 / 11$ and their aftermath triggered a considerable growth of political demand for area expertise, especially for the regions from North Africa to Southeast Asia shaped by Islam. In this context, the "culturalization" of global conflicts, most effectively promoted by Samuel Huntington's

15 Gareth Austin, "Global History in (Northwestern) Europe: Explorations and Debates," in Beckert and Sachsenmaier, Global History Globally, 21-44: here: 24. For a broader picture, see Andreas Eckert, "Area Studies and the Writing of Non-European History in Europe," in Transnational Challenges to National History Writing, eds. Matthias Middell and Lluís Roura (Houndsmill and Basingstoke, 2013), 140-163.

16 David L. Szanton, "Introduction. The Origins, Nature and Challenges of Area Studies in the United States," in The Politics of Knowledge. Area Studies and the Disciplines, ed. David L. Szanton (Berkeley, 2004), 1.

17 Eckert, Area Studies; Anne Kwaschik, Der Griff nach dem Weltwissen. Normative Ordnungen, kognitive und institutionelle Praktiken der Area Studies im 19. und 20. Jahrhundert, unpublished Postdoctoral [Habilitation] thesis, Free University, Berlin 2016.

18 Thus, area studies in the United States are the best-researched example. See for instance Immanuel Wallerstein, "The Unintended Consequences of the Cold War Area Studies," in The Cold War and the University: Toward an Intellectual History of the Postwar Years, ed. Noam Chomsky (New York, 1997), 195-232; Vincente L. Rafael, "Regionalism, area studies, and the accidents of agency," American Historical Review 104, no. 4 (1999): 1208-1220; David Engerman, Know Your Enemy. The Rise and Fall of America's Soviet Experts (New York, 2009); Szanton, The Politics of Knowledge.

19 See Mark Berger, Under Northern Eyes. Latin American Studies and US Hegemony in the Americas, 1895-1980 (Bloomington, IN, 1995). 
concept of a "clash of civilizations," proved to be particularly challenging. ${ }^{20}$ At the same time, the end of the Cold War produced considerable effects. As mentioned above, the emergence of area studies after World War II was partly due to strategic interests of Western and Eastern governments in the era of competition of ideological systems. Political interests changed after 1989. Local and supranational concerns at least partly replaced the demand for information exclusively related to nation states. Moreover, the old holistic understanding of a territorially bounded culture, which was constitutive for area studies, gave way to a concept of culture as process and practice; of culture as a "work in progress." ${ }^{21}$ The detachment of culture from its spatial references led to a new focus on processes such as cultural globalization and diaspora. ${ }^{22}$ These phenomena led to the dissolution of the traditional idea of culture and space as being congruent. On the other hand, it is impossible to conceptualize "diaspora" without any symbolic spatial structure. What does this mean for area studies? There is a growing insight that "culture" cannot be defined as a spatial container, but that the various "areas" must be understood as the result of processes of cultural marking. "What is African about Africa" should be the question, not a given assumption. The analysis of social networks, diasporas, cultural entanglements, and affinities should follow concrete movements in space instead of distinguishing between already defined "localities" or "regions" and a vague idea of "the global."23 While numerous new studies follow this path and demonstrate a fruitful cooperation between area studies and global history, ${ }^{24}$ another eternal problem is still much disputed: The relationship between area studies and the so-called systematic disciplines such as history, sociology, economics, or political sciences. Area studies specialists tended to make efforts to follow the standards of the disciplines regarded as "systematic" and they produced "evidences of achievement" meant to prove their contributions to the "mother disciplines." ${ }^{25}$ However, few scholars

20 Samuel P. Huntington, The Clash of Civilization and the Remaking of World Order (New York, 1996). One of the many critics was Amartya Sen, Identity and Violence. The Illusion of Destiny (New York, 2006).

21 Ulf Hannerz, "The World in Creolization," Africa 57 (1987): 546-559, here: 550.

22 One by now classic example is Paul Gilroy, The Black Atlantic. Modernity and Double Consciousness (Cambridge, MA, 1993).

23 See Frederick Cooper, "Africa's Past and Africa's Historians," Canadian Journal of African Studies 34, no. 2 (2000): 298-336, here: 299.

24 See the articles in Birgit Schäbler, ed., Area Studies und die Welt. Weltregionen und neue Globalgeschichte (Wien, 2007).

25 A good example of this is the volume Robert Bates et al., eds., Africa and the Disciplines. The Contributions of research in Africa to the Social Sciences and Humanities (Chicago, 1993). See also Cooper, Africa's Past. 
systematically discussed to what extent knowledge about a specific area could question the theories, epistemologies, and boundaries of a discipline. ${ }^{26}$ In addition, it could be asked whether the massive attacks on area studies, ${ }^{27}$ which were launched in the 1980s and 199os especially in the United States, resulted from the considerable self-confidence of certain disciplines, or whether the contrary is true: That representatives of certain disciplines were worried that external input could be threatening. In turn, area studies scholars as well as historians of non-European regions complained about the growing devaluation of language training, field research, and lack of cooperation with researchers in the localities. Even those who agree that area studies could never provide a serious alternative to disciplinary practices insist on the fact that area studies have always been a valuable enlargement, because in the context of area studies intellectual communities were formed, which stressed that scholars should "know something about someplace."28

The case of Germany is an interesting example of the complex relationship between area studies and global history. In Germany too, "an area specialization within Non-western history ... has been by far the most important avenue towards global history."29 However, the specific institutional parameters of German academia resulted in a kind of outplacing of expertise on non-European world regions. While in the overall majority of history departments the proportion of scholars exploring history outside Europe is very low (in many cases there is not even a single tenured position devoted to these parts of the world), the task of studying Africa, Asia, the Americas, and the Middle East is largely relegated to small specialized fields such as Islamic Studies or Sinology, still characterized by strong philological traditions and mostly organized in "area studies" departments. To date, these small disciplines have tended to nurture their own forms of academic training. Furthermore, they

26 Steve Feiermann, "African History and the Dissolution of World History," in Africa, eds. Bates et al., 167-212 does this very effectively in the case of history.

27 These attacks were mainly orchestrated by economists and social scientists, but historians also took the opportunity to put into question the usefulness of dealing with the past of non-European areas. In the early 1990s, the seventeenth-century specialist John Kenyon noted with satisfaction that in "history departments hastily cobbled-up courses on Indochina or West Africa faded away as soon as these areas ceased to be of immediate current concern." Quoted in Richard J. Evans, In Defence of History (London, 1997), 178.

28 For recent debates about the relations between area studies and other approaches such as transregional studies, but also about a definition of area studies that goes beyond the "Global South," see Katja Mielke and Anna Katharina Hornidge, eds., Area Studies at the Crossroads. Knowledge Production after the Mobility Turn (New York, 2017).

29 Jürgen Osterhammel, "Global history in a national context: the case of Germany," Österreichische Zeitschrift für Geschichtswissenschaft 20, no. 2 (2009): 40-58, here: 44-45. 
entertain their own disciplinary public spheres through separate journals, conferences, and associations. As a consequence, the bulk of area expertise in Germany remains somewhat fragmented, which prevents researchers focusing on other parts of the world from building an intellectual counterweight to predominantly Eurocentrically structured fields such as historiography. ${ }^{30}$

Despite these structural limitations, the number of collaborative projects between representatives from area studies and history departments has been growing slowly but steadily. This process has met with support from influential academic and political circles, which came to promote interregional and interdisciplinary research. In this regard, one major step was the recommendation of the German Science Council in 2005 to establish interdisciplinary area studies centers at some universities. During the past few years, and due to comparatively substantial funding for the humanities and particularly area studies, a richer institutional landscape has started to emerge, with the possibility and purpose of strengthening interdisciplinary cooperation by fostering global and transnational historical research. There are reasons to assume that the growing interest in transnational and transcultural themes will provide new connecting points between the field of history, area studies, and subfields such as Atlantic or Indian Ocean history. In this way, the historiography of China, India, Africa, and other parts of the world may ultimately start to lose its character as a garden of marginal "orchid fields" and gain significance within the professional community of German historians. ${ }^{31}$ On the other hand, historians of India or Africa who stress the importance of source-based empirical research, note with concern the fact that global historians often rely on generalizations of secondary literature. Margrit Pernau, for instance, warns against the widespread ignorance of sources written in non-European languages. According to her, the exclusive use of source material in European languages implies the danger of reproducing colonial views or becoming caught up in absurdities; then global history runs the risk of degenerating into "historiography light." 32

While global history currently seems to be everywhere and is celebrated "to be one of the most significant developments in the discipline of history since the social history revolution of the $1970 \mathrm{os,"33}$ some protagonists of global history are increasingly turning to a modus of self-criticism. Most notably, Princeton historian Jeremy Adelman, an eminent historian of Latin America and one of

30 Sachsenmeier, Global Perspectives, 122-125; Matthias Middell, "Area Studies under the Global Condition. Debates on Where to Go with regional or Area Studies in Germany," in Self-reflexive area studies, ed. Matthias Middell (Leipzig, 2013), 7-57.

31 Sachsenmeier, Global perspectives, 161.

32 Margrit Pernau, "Global History—Wegbereiter für einen neuen Kolonialismus," geschichte transnational, 17 December 2004, http://geschichte-transnational.clio-online.net/forum. Becker and Sachsenmaier, "Introduction," in Global History Globally, 1. 
the promoters of global history in the United States, recently published an essay in which he laments that suddenly global historians seem out of step with their time. "A powerful political movement arose against 'globalism.' Whitesupremacists and Vladimir Putin fans from the Traditionalist Worker Party in the US proclaim as their slogan that 'Globalism is the poison, nationalism is the antidote." Adelman takes this political movement as a starting point for substantial self-critique. Despite the mantras of integration and the inclusion on the planetary scale, he argues, global history came with its own segregation, starting with language. Historians working across borders merged their mode of communication in ways that created new walls; in the search for academic cohesion, English became "Globish." Global History would not be possible without the globalization of the English languages. On the other hand, Adelman writes, it is hard not to conclude that global history is another Anglospheric invention to integrate the Other into a cosmopolitan narrative "on our terms, in our tongues." According to Adelman, global history faces two seemingly opposite challenges for an interdependent, overheating planet:

If we are going to muster meaningful narratives about the togetherness of strangers near and far, we are going to have to be more global and get more serious about engaging other languages and other ways of telling history. Historians and their reader-citizens are also going to have to resignify the place of local attachments and meanings. Going deeper into the stories of Others afar and Strangers at home means dispensing with the idea that global integration was like an electric circuit, bringing light to the connected. Becoming inter-dependent is not just messier than drawing a wiring diagram. It means reckoning with dimensions of networks and circuits that global historians - and possibly all narratives of cosmopolitan convergence-leave out of the story: lighting up corners of the earth leaving others in the dark. ${ }^{34}$

Adelman articulates a number of points of criticism concerning global history regularly expressed by area historians, such as the obsession for mobility and entanglement while ignoring immobility as a crucial feature of the global condition; or the dominance of English that usually comes along with the neglect of sources and literature in other languages. These are also challenges for the field of global labor history.

34 Jeremy Adelman, "What is global history now?" https://aeon.co/essays/is-global-historystill-possible-or-has-it-had-its-moment. For a forceful rejoinder: David Motadel and Richard Drayton, "Discussion: The Future of Global History," Journal of Global History 13, no.1 (2018): 1-21. 
More generally, many of the "scenes" presented in the previous paragraphs are also relevant in order to understand the relationships between current efforts to employ global perspectives in writing histories of work and area-based historical research. One of the virtues of labor history in recent decades has been its micro-historical focus on workers and work in relation to the range of social processes in a particular milieu, for example race, gender, and ethnicity. If we increasingly look beyond both locality and region toward wider spatial relationships, what do we learn apart from the insight that we are confronted with fuzzy categories and fuzzy constellations? Labor historians face the difficulty of focusing on the necessarily specific historical trajectories in certain localities in Europa, Asia, or Africa and across specific patterns of regional migration, without losing sight of the wider context. A growing number of labor historians have attempted to write a history of labor and work infused with both specificity and comparison; that sees shared entanglements as bi- or multi-directional rather than unidirectional, and that does not impose a model from one period, nation, or region onto another. These efforts have been subsumed under the rubric of Global Labor History. ${ }^{35}$

As far as its methodological status is concerned, it is more an "area of interest" than a theory or school to which everyone must subscribe. It is not "a vertical organization, but a network continuously assembling and breaking up in relation to specific research projects; it does not aim for a new 'grand narrative,' but rather to partial syntheses based on multiple empirical research and various intellectual interpretations." ${ }^{36}$ One of its main concerns so far has been to integrate more systematically the "Global South" into labor historiography, at both the intellectual and the institutional level. Widening the focusmoving beyond workers in the West to look at those in Asia, Latin America, and Africa - formed one of the starting points of global labor history and implied

35 The key text in this field is still Marcel van der Linden, Workers of the World. Essays Toward a Global Labor History (Leiden, 2008). He also produced numerous essays to map the field, most notably "The Promise and Challenges of Global Labor History," International Labor and Working Class History 82 (2012): 57-76. For other efforts in mapping see Leo Lucassen, "Working Together: New Directions in Global Labour History," Journal of Global History 11, no. 1 (2016): 66-87; Andreas Eckert, "Why all the fuss about Global Labour History?" in Global Histories of Work, ed. Andreas Eckert (Berlin/Boston, 2016), 3-22; Andreas Eckert and Marcel van der Linden, "New Perspectives on Workers and the History of Work: Global Labor History," in Global History Globally, 145-161.

$3^{6}$ Christian G. De Vito, "New Perspectives on Global Labour History. Introduction," Workers of the World 1, no. 3 (2013): 7-31, here: 12. 
the incorporation of scholarship on and from these areas. It soon became evident that North-Atlantic-focused labor history, with its emphasis on wage workers, industries, and cities, has provided a highly incomplete picture of labor and has ignored the vast amount of labor in the countryside, outside of wage relations, and in agriculture. In a global labor perspective, the slave and the sharecropper are put next to the wage worker, and the focus is on the complex entanglements between them. This understanding of the global scope of labor history undermines a core narrative that emphasizes the development of labor toward contract, freedom, and formalization. In addition, via the "detour" of the "Global South," historians of the West re-discovered the importance of agrarian or different forms of non-wage labor and began to locate, for Europe and North America, the extensive and complicated "grey areas" replete with transitional locations between the "free" wage laborers and other forms of labor, to take into consideration that households often combine several modes of labor, and to have an eye for the possibility that individual laborers can combine different modes of labor, both synchronically and diachronically. ${ }^{37}$

These more recent efforts, however, should not let us ignore the fact that, for instance, Latin American historians, like their colleagues in North America and Europe, have been studying the particularities of labor in their regions for decades. ${ }^{38}$ African and Indian historians have done this more recently, but with a focus either on area or on specific types of labor, for example plantation labor. ${ }^{39}$ For a long time, European and Western labor historians tended to "universalize" their views, often based on rather specific examples. They ignored for instance the work of Caribbean specialists, for whom the relationship between plantation labor and global capitalism has been central since the work of C.L.R. James and Eric Williams in the 1930 s and 1940 os $^{40}$ Perspectives in the context of (post-)colonialism have been central in many attempts to globalize historical studies. ${ }^{41}$ This appears also to be true with regard to labor history. In this field, the mutual relationship between social change with the colonizing

$37 \quad$ Van der Linden, Workers of the World, 32.

38 See James P. Brennan, "Latin American Labor History," in The Oxford Handbook of Latin American History, ed. José C. Moya (Oxford, 2011), 342-366.

39 Rana Behal, One Hundred Years of Servitude: Political Economy of Tea Plantations in Colonial Assam (New Delhi, 2014); Abdul Sheriff, Slaves, Spices and Ivory in Zanzibar (London, 1987). Much of the literature on plantation labor in Africa has been produced by North American scholars. See e.g. Frederick Cooper, From Slaves to Squatters. Plantation Labor and Agriculture in Zanzibar and Colonial Kenya, 1890-1925 (New Haven, 1980).

40 Eric Williams, Capitalism and Slavery (Chapel Hill, 1944); C.L.R. James, The BlackJacobins. Toussaint L'Ouverture and the San Domingo Revolution (New York, 1938).

41 Conrad, Global History, 53-57. 
countries and the colonized territories continues to be of interest. The crucial question that remains open is how colonization shapes labor history. One important reference here is the slave plantation as a formative experience in developing large-scale, closely supervised enterprises. ${ }^{42}$ How did this experience shape the ideas, organization, and practice of labor in the world? Another is the point Karl Marx made: According to him, the availability of land and the possibility of migration are obstacles to original accumulation. Why did this problem remain even after relatively long-term and intense colonization efforts? In fact, there is some reason to argue that this concept from Marx might gain new importance in the African context, given for example the rush for land in Africa and the political and economic conflicts this entails. ${ }^{43}$

One of the major insights of global approaches to the history of labor has been the emphasis on numerous hybrid constellations and on the ambiguity of established concepts, definitions, and distinctions. Area-based studies have played a major role here. For example, historians of Brazil show that slaves were ordered by their owners to leave the mansion or the plantation and work for wages, but to bring back part of their earnings. ${ }^{44}$ Other combinations of slave and wage labor, or serfdom and capitalism (such as in Russia around 1900), would seem to relativize Karl Marx's and other classical writers' theses of the outstanding importance of contractually free wage labor as a defining element of capitalism. ${ }^{45}$ Comparing Russia and England between 1780 and $185^{\circ}$, Alessandro Stanziani highlights: "Servants, wage earners, the poor, criminals, slaves, and serfs all had to respond to common general principles of utility and efficiency." ${ }^{\prime 6}$ In societies where slavery was central —as in the Americas, Africa, and elsewhere - the distinction between "free" and "unfree" became essential, especially once slavery as an "institution" became a public abomination, at least from the late eighteenth century onward. In these contexts, the clear

42 Sidney Mintz, Sweetness and Power. The Place of Sugar in Modern History (Harmondsworth, 1985).

43 Catherine Boone, Property and Political Order. Land Rights and the Structure of Conflict in Africa (New York, 2014).

44 João José Reis, "The Revolution of the Ganhadores: Urban Labor, Ethnicity and the African Strike of 1857 in Bahia, Brazil," Journal of Latin American Studies 29 (1997): 355-393.

45 Alessandro Stanziani, "The Legate Statute of Labour from the Seventeenth to the Nineteenth Century. Russia in a Comparative European Perspective," International Review of Social History 54 (2009): 359-389; Alessandro Stanziani, Bondage. Labor and Rights in Eurasia from the Sixteenth to the Early Twentieth Century (New York/Oxford, 2014); Alessandro Stanziani, ed., Le Travail Contraint en Europe et en Asie, XVI-XXe siècles (Paris, 2010).

46 Alessandro Stanziani, "The travelling panopticon: labor institutions and labor practices in Russia and Britain in the eighteenth and nineteenth century," Comparative Studies in Society and History 51, no. 4 (2009): 715-741, here: $73^{2}$. 
divide between "slavery" and "freedom" turned into the source of all sorts of social and political anxieties and fostered various logics of continuity and discontinuity. On this topic, again, not the least Brazilian historians have stressed that during the nineteenth century no distinct division existed between slaves and "freed" workers with regard to the utilization of extra-economic coercion. On the other hand, as their studies show, the ambivalence of the concept of "freedom" indicated sharp social conflict on the ground, related to specific work arrangements. Among former slaves, "freedom" was usually experienced as precarious, limited, or even spurious, but it nevertheless constituted a relevant category and a crucial aspiration..$^{47}$ One insight from this research is that even if there seems to be a long-term trend towards "free wage labor," so-called free labor "cannot be seen as the only form of exploitation suitable for modern capitalism, but rather as one alternative among several."48

The study of regions outside the North Atlantic realm very much shaped debates about the global rise of precarious and informal work, currently an intensely discussed theme both in scholarly and political fields. Although some Africanists insist that "African economies are the most informalized in the world," non-waged economic activities, unregulated by law and unprotected by social regulations or services, became increasingly visible in many parts of the world, including the core regions of the North Atlantic world. 49 "Precarity"

47 See Henrique Espada Lima, "Freedom, Precariousness, and the Law: Freed Persons contracting out their Labor in Nineteenth-Century Brazil," International Review of Social History 54, no. 3 (2009): 391-416; Marcelo Badaró Mattos, "Experiences in Common: Slavery and 'Freedom' in the Process of Rio de Janeiro's Working Class Formation (1850-1910)," International Review of Social History 55, no. 2 (2010): 193-213; Sidney Chaloub, "The Precariousness of Freedom in a Slave Society (Brazil in the Nineteenth Century)," International Review of Social History 56, no. 3 (2011), 405-439; Sidney Chaloub, "The Politics of Ambiguity. Conditional Manumission, Labor Contracts and Slave Emancipation in Brazil (1850s to 1888)," International Review of Social History 6o, no. 2 (2015): 161-191. For a thoughtful reflection on the unfree-free divide referring to the crucial contribution of Brazilian historians, see Ravi Ahuja, "A Freedom Still Enmeshed in Servitude. The Unruly 'Lascers' of the SS City of Manilaor, a Micro-History of the 'Free Labour' Problem," in Working Lives and Worker Militancy. The Politics of Labour in Colonial India, ed. Ravi Ahuja (New Delhi, 2013), 97-133, especially 97.

48 Marcel van der Linden, "Labour History Beyond Borders," in Histories of Labour. National and International Perspectives, eds. Joan Allen et al. (Pontypool 2010), 353-383, here: 368 .

49 Kate Meagher, "The Scramble for Africans: Demography, Globalization and Africa's Informal Labor Markets," Journal of Development Studies 52 (2016): 483-497, here: 485. For an insightful analysis of the categories "informal" and "precarious" in the African context, see Frederick Cooper, "From Enslavement to Precarity? The Labour Question in African History," in The Political Economy of Everyday Life in Africa. Beyond the Margins, ed. Wale Adebawi (Oxford, 2017), 135-156. For a powerful argument about the global importance of informal labor relations, see Jan Breman and Marcel van der Linden, "Informalizing the 
has also become a fashionable new concept in labor studies. It seems to imply the view that while in the past, capital was striving to systematically extract surplus value from a large and growing work force that at the same time had to be tamed, today more and more workers have apparently become unnecessary. However, some scholars have drawn attention to the fact that precarity does not represent a particular phase of capitalism, but that it is an inherent characteristic of capitalist labor. ${ }^{50}$ The discovery of the "informal" and "precarity" went hand in hand with the observation that full-time wage labor with relatively good social benefits over the course of an entire career was not a global norm, but instead the exception in many parts of the world; the contingent product of a particular conjuncture in twentieth-century world history. This in turn led to the insight that the male proletarian does not represent the quintessential worker, but is instead one among a number of categories of workers whose histories are connected. ${ }^{51}$ Rather than being exceptions confirming the rule, parts of Africa and Asia represent contexts in which capitalist production regimes and their related forms of employment have confronted social practices and cultural forms that questioned the normative pretenses of the wage relation and challenged the universalism inherent in ideologies of "free" commodity-producing work.

Lastly, area studies were also crucial in creating a new impetus for rethinking central concepts of labor history. All the core concepts of "traditional" labor history are primarily based on experiences in the North Atlantic region and are thus in need of critical re-evaluation. ${ }^{22}$ There is no simple solution to this problem, but a growing consciousness that we should not implicitly assume how "labor" and "work" are to be understood, but define and trace much more precisely their changing and varying meanings. ${ }^{53}$ In a recent article, Anne Kelk Mager shows a competition for semantic ground between two main concepts pertaining to the domain of "work" among isiXhosa speakers in South Africa. This competition took place against the backdrop of their being increasingly affected by European notions of "work" and "labor." As Mager demonstrates, the renegotiation of ideas of "work" in isiXhosa was a much more complex

economy: the return of the social question at a global level," Development and Change 45, no. 5 (2014): 920-940.

$50 \quad$ Marcel van der Linden, "San Precario: A New Inspiration for Labor Historians," Labor 11 (2014): 9-21.

$5^{1}$ This is one of the major points made by van der Linden, Workers of the World.

$5^{2}$ Van der Linden, Labor History beyond Borders, 365 .

53 See Jörn Leonhard and Willibald Steinmetz, "Von der Begriffsgeschichte zur historischen Semantik von 'Arbeit," in Semantiken von Arbeit. Diachrone und vergleichende Perspektiven, eds. Jörn Leonhard and Willibald Steinmetz (Cologne, 2016), 9-59. 
process than colonial notions unilaterally affecting pre-existing concepts. Indeed, labor and employment in this region were not just abstract ideas, but concrete arenas of negotiation of economic conditions. Mager's analysis shows how linguistic understandings of concepts of "work" were shaped by the events of the nineteenth century, including the expansion of colonial rule, but also how these concepts themselves influenced isiXhosa speakers' decisions and actions during this period. ${ }^{54}$

A fundamental challenge for global perspectives on the history of labor is the globally very uneven existence of source material and the availability of data. A large project by the International Institute of Social History in Amsterdam entitled "Global Collaborative on the History of Labour Relations" shows both the possibilities and limits of large-scale, data-based global labor history enterprises. The core of this project is a universal taxonomy of labor relations that aims to map different types of labor relations in various world regions between 1500 and 2000. ${ }^{55}$ The taxonomy basically distinguishes between four forms of labor: Non-work, reciprocal labor, tributary labor, and commodified labor; either connected with the household, the community, or the market. These types are further elaborated in nineteen different types of labor relations at the individual level, for instance in the category of the household: Leading producers, kin producers, kin non-producers, servants, and redistributive laborers. The project chose five cross-sections in time: 1500, 1650, 1800, 1900, and 2000 , as well as 1950 for Africa. On the basis of the data collected by the participating specialists on specific regions and cross-sections, the collaboratory attempts to analyze major shifts in labor relations by asking, for instance, when a specific type of labor relation gave way to another, or how these transitions could be explained and connected in a global context. Without any doubt, this project offers a solid base from which to analyze shifts in labor relations over time within societies, and which allows for interregional and worldwide comparisons. One drawback seems to be the strong role of demographical data as a starting point for examining each geographical unit and cross-section, given

54 Anne Kelk Mager, "Tracking the Concept of 'Work' on the North Eastern Cape Frontier, South Africa," in: Doing Conceptual History in Africa, eds. Axel Fleisch and Rhianoon Stephens (New York/Oxford, 2016), 73-90.

My presentation of the project follows Lucassen, New Directions, 68-70. For detailed information see https://collab.iisg.nl/labourrelations/about. Among the publications that emerged from this project are: Karin Hofmeester and Christine Moll-Murata, eds., The Joy and Pain of Work. Global Attitudes and Valuation 1500-1650 (Cambridge, 2012); Marcelo Badaró Mattos et al., eds., Relações Laborais em Portugal et no Mundo Lusófono. História e Demografia (Lisbon, 2014); Karin Hofmeester and Pim de Zwart, eds., Colonialism, Institutional Change, and Shifts in Global Labor Relations (Amsterdam, 2017). 
the fact that for a continent such as Africa, this data is very sketchy and unreliable until right into the twentieth century. Moreover, the taxonomy does not really allow the capturing of overlaps and "grey zones" in individual labor relations. The Africa-related publications emerging from this project so far provide interesting new insights, but also refer to the limits of the database-driven approach for the history of African labor and its global connections, especially for the periods before $1900 .{ }^{56}$

The project sets an example for collaboration between scholars from many parts of the world, including historians from what is now called the "Global South." Despite various and successful efforts, however, one cannot ignore the structural inequalities that shape the field of Global Labor History in many ways: For scholars in Asia or Africa, access to sources and literature is limited, and funding for research and conferences is rarely available. The important thing for the practice of Global Labor History is, according to Van der Linden, "to follow the traces of interest to us wherever they may lead: across political and geographical frontiers, time frames, territories and disciplinary boundaries." 57 This journey presents a considerable demand not only on the intellectual and linguistic skills of the researcher, but also on their finances. Skepticism about global history approaches is not only due to frustrations about the lack of resources though. In many parts of the "Global South," the persistent preoccupation with national history also represents an obstacle to global perspectives. In essence, given the long history of Eurocentric knowledge production and academic hierarchies, there is a widespread sense of Global (Labor) History as just another hegemonic Western project.

\section{A Luta Continua}

Although some protagonists of Global (Labor) History come along as missionaries, most representatives of this field would agree that this is not the only game in town, but one perspective among others. To consider Africa, Asia, or Latin America in relation to global history suggests valuable lines of connection to other fields of history and new perspectives on a number of topics, but also jumping on bandwagons. There is no need for historians of the "Global South" to prove that they are also capable of employing a global perspective, and thus entitled to historiographical citizenship, although some seem to

$5^{6}$ See Karin Hofmeester et al., "No Global Labor History without Africa: Reciprocal Comparison and Beyond," History in Africa 41 (2014): 249-276.

Van der Linden, Promise, 62. 
feel a kind of pressure and even react defensively. In fact, as we have seen, there is a long tradition of placing these world regions in the long sweep of global history, not the least in the realm of labor. Global histories of labor require the cooperative spirit of teamwork and conversations transcending all kinds of boundaries - language boundaries and others - although the Global Collaborative on the History of Labor Relations indicates that collaborative projects focusing on numerous world regions imply a set of methodological problems that are not easy to solve. It is still worth taking the trouble to write histories of labor that put the subsistence laborer, the slave and the sharecropper next to the wageworker, and that keep the entire world in mind, even when focusing on a specific area. Finally, it is important to emphasize that global labor history not only gained momentum from good intentions, intellectual declarations, and the energy of a number of historians. During the past years, a growing institutional and financial fundament has been built that supported a further expansion of historical research at a global and transnational level. It is currently unclear how stable this fundament is, but without any doubt, global historical perspectives gained an important place in the historiography of labor within a relatively short period of time. The esteem of area studies as well as the increasing (though still limited) incorporation of historians from the South into new global communities of scholars are crucial elements in this context. The global turn might lose some of its dynamics, but the insights and perspectives that came with it will continue to shape historical research on labor and other topics. 